\title{
DISTRIBUTION OF THE SENSORY CELLS IN THE CRISTA AMPULLARIS IN HUMAN EARS.
}

KOZO WATANUKI, M.D., YOSHIKI SATO, M.D., JIRO HOZAWA, M.D. AND KAZUTOMO KAWAMOTO, M.D.

Department of Otorhinolaryngology, Tohoku University School of Medicine, Sendat

(Director: K. Kawamoto, M.D.)

The aim of the present study is to investigate more precisely the distribution of the sensory cells, the over-all cytoarchitecture and sensory cell populations of the cristae. The inner ears from 35 individuals whose age ranged from newborn to 90 years old were obtained within 10 hours post-mortem. Their medical records showed no evidence of auditory or vestibular disorders or therapy with ototoxic drugs.

Using a silver staining method, surface preparations of the vestibular sense organs were studied by light-microscopy. Graphic reconstructions were made for the whole area of the crista and the macula. The sensory cells with large free surface predominantly occupied the central region of the crista and the striola of the macula. The sensory cells in the peripheral region of the crista and in the extra-striolar region of the macula showed smaller free surfaces and they varied less in size. The free surfaces of the supporting cells, however, no size differences. The sensory cells were more in number in the peripheral regions of the cristae and in the extra-striolar regions of the maculae. In the cristae, almost 6800 sensory cells were observed in a 0.9 square $\mathrm{mm}$ area. In the saccular macula, about 16,000 sensory cells were discovered in a 2.2 square $\mathrm{mm}$ area and almost 30,000 sensory cells were found in a 3.5 square $\mathrm{mm}$ area in the utricular macula.

$79 \mathrm{~A}-0545.24010$

\section{ヒト半規管膨大部稜の感覚細胞分布}

\author{
東北大学医学部耳舅咽喉科教空 (主任: 河本和友教授) \\ 綿貫幸三・佳藤良樹・朴沢二郎 \\ 河本和友
}

\section{1 粕 言}

前庭感覚上皮の表面構造の研究は Retzius (1884 $)^{11}$ 最初とする。最近では 1969年に Lindeman² がモルモ ッ卜前庭感觉上皮の取出し標本を用いて，感觉細胞の分 布拉び数の測定などを行っている。 また Rosenhall ${ }^{3}$, 6).5) は 1972年㧍よび1.975年に，ヒ卜に执ててこれらの 研究を行い，定量的な報告を行っている。これらの研究 は Engström的等によつて開発されたオスミューム酸固 定と位相差顕微鏡によつてなされたものであるが，銀染 色栖本に上る光学顕微鏡観察によると, 組織表面の構造 をるつと明膫な刘照で観察することができる，本研究で 泣, 上卜前庭半規管膨大部稜感觉上皮の全体表面蝺造を
銀染色標本により示寸とともに，感覚細胞数を初めて直 接算定したので報告する。

\section{2 材料及び方法}

病理剖検に挍いて得られた年令 $0 \sim 90$ 才の35例の内耳 老使用した，側頭骨採取時問は死後10時間以内であつ た。これらの例は全て，耳疾患および耳毒性抗生物質投 与の既往歷を有していなかつた。側頭骨採取は Schukn一 echt plug7〕によった. 球形のうおよび卵形のう膜部を 破り, $5 \mathrm{cc}$ の $0.5 \%$ 硝酸銀溶液にて約 1 分閒前庭迷路を 灌流した。泠暗所にて約 1 時問ホルマリンで固定し，緩 街液中にて脜迷路を解体して影微鏡光に感覚上皮を露光 した，黄裀色に変色した時点で再び10\%ホルマリンに投 
入して24時間固定してから, 感覚上皮の剥離を行つた ${ }^{8)}$, 感覚上皮全体を40倍で分割写真撮影の後に再構成し，面 積, 細胞数の測定を行つた。測定標準として Eleitz-Wetzler $(\mathrm{I} / 100 \mathrm{~mm})$ ミクロメーターを用いた。

\section{3 結 果}

ヒト内耳膜迷路を骨迷路から剝離すると図 1 の如くで あり，他の哺乳動物のそれと基本的に異ならない 膨大 部稜感覚上皮は輨状の稜表面を扮拈い, 半規管㧍よび卵 形のら側は移行上皮であり，両側方は半月状丘上皮に移 行している. 後半規管では, 感覚上皮が円味のある角の ほぼ長方形をなしているが，前半規管および外側半規管 では，1ないし2角が卵形のうあるいは半規管方向のや や斜めに扇状に伸展し, 長方形の形はかなりくずれたも のとなっている. 感鸴上皮表面では支持細胞が密に接続 し, 感覚細胞を周囲から囲み, 表面全体として網状膜を 形成している. 感営細胞 1 個は通常 $3 \sim 5$ 個の支持細胞 により取囲まれている，感覚上皮中心部では，自由表面 の大きい感覚細胞が屡々認められた. 辺縁部では, 自由 表面の小さいほぼ均等の感覚細胞がみられた. 支持細胞 の自由表面は場所により差異がみられず, 形は異なるが その大きさは, 辺縁部における感覚細胞表面とほとんど 同じ大きさであつた. Rosenhal14) が報告したとうり， 感覚細胞は感覚上皮中心部より辺縁部に密に分布してい

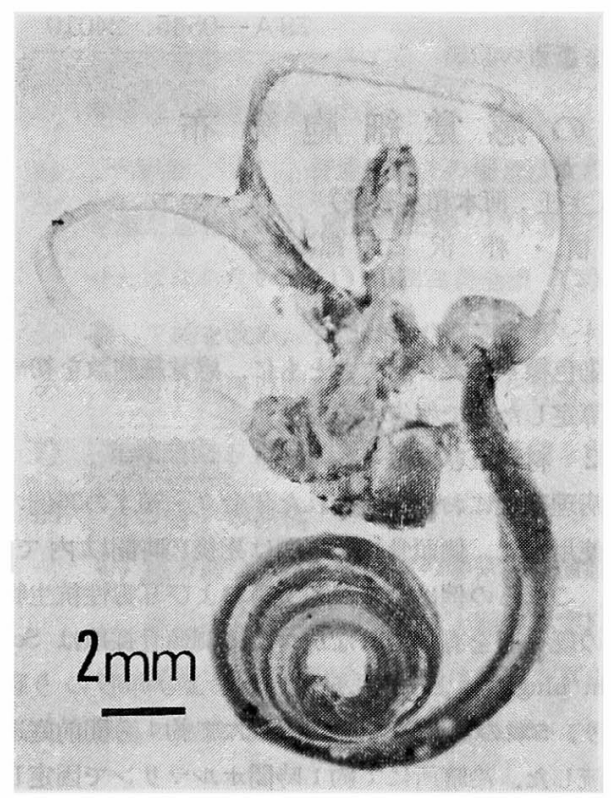

図 1 ヒト側頭骨膜迷路の全体像. 左耳. 5 倍.
るが, 中心部は徐々に辺縁部に移行しており, 構造上明 確な境界はみられなかつた．銀染色により感覚上皮の表 面構造を明膫に観察することができ, 全体の分割撮影写 真を組合わせることにより膨大部稜全体を鳥撖すること ができた（図 2，4）。

感覚細胞の中で I 型と II 型細胞の区別は, I 型のフラ スコ型, II 型の円柱型という形態の差からモルモットを 用いて簡単に行われ, それらの広範囲にわたる分布状態 を観察できたが9,，本研究におけるヒトの場合には，死

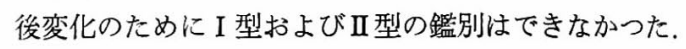
膨大部稜感覚上皮の面積および, 感覚細胞の全直接算定 数を表に示した (表1). 同時に, 球形のら斑および卵形 のう斑の感覚上皮についても, それらの算定数を併記し た. 年令50才以上の例では, 通常, 膨大部稜感覚上皮の 中心部, 球形のうおよび卵形のう斑感覚上皮の Striola に細胞配列のみだれが認められ，これらの部位における ある程度の感覚細胞脱落を表わしていると考えられた。

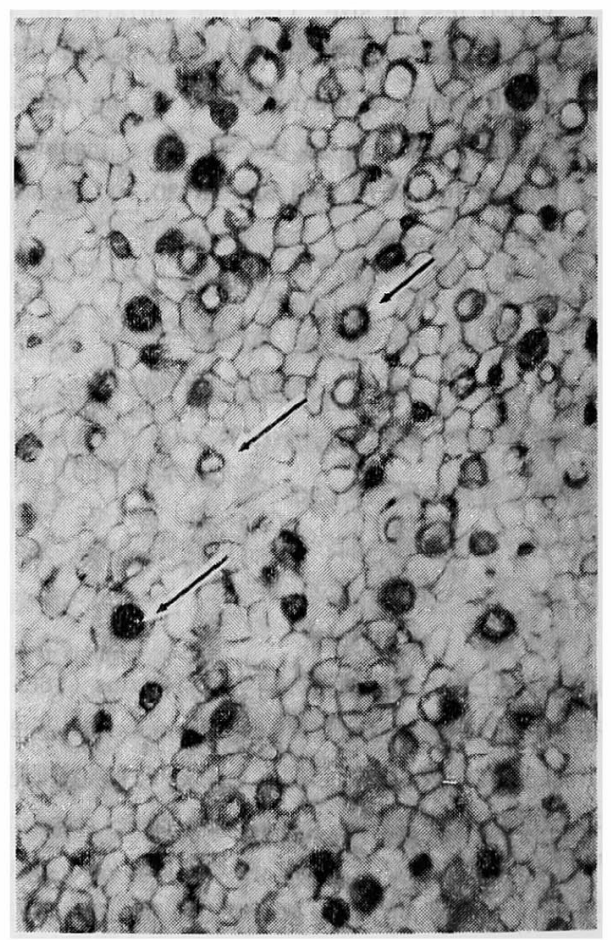

図 2 ヒト半規管膨大部稜感覚上皮中心部 の表面像. 円形の感覚細胞表面(矢印) とそれを取巻く多角形の支持細胞とが 明瞭である. 76 才男. 右外側半規管膨 大部稜. 感覚細胞の脱落が中等度にみ られる，800倍， 


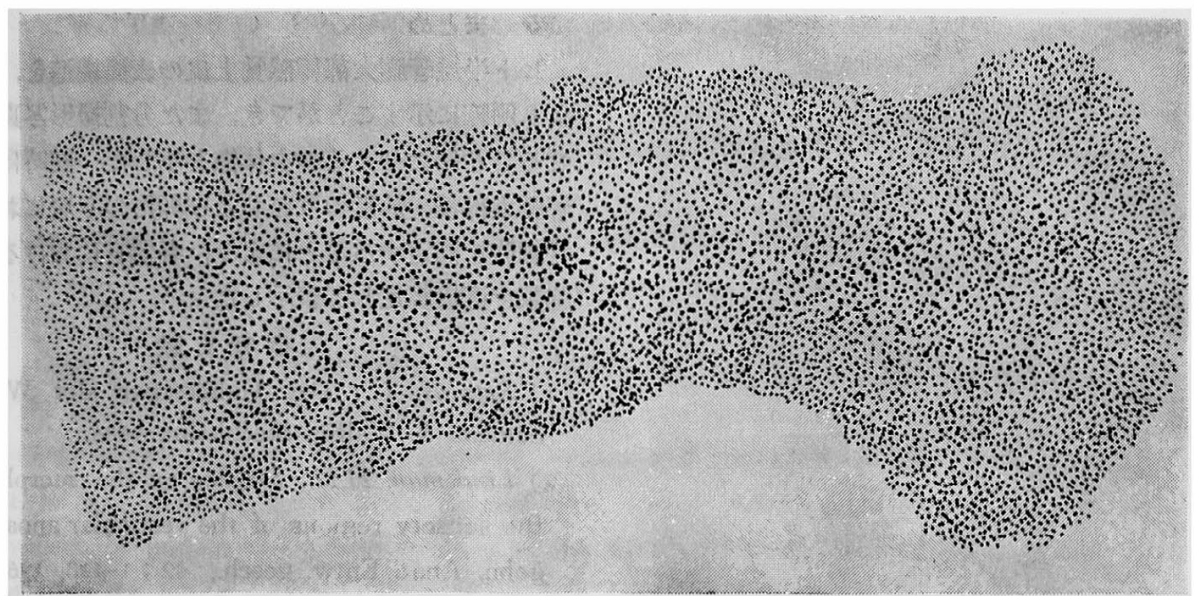

図4 半規管膨大部稜感覚上皮における感覚細胞分布. 各黒点は感覚細胞表面を正確に写 しとつてある. 15才男. 左前半規管膨大部稜. 中心部では疎に分布し, 辺縁部では密 に分布している。中心部では大型のものがみられる．51倍。

\section{4 考 按}

実験動物の前庭感覚上皮表面構造の部分的スケッチは Retzius (1884)1) の書にみられ，その後，岩田 ${ }^{10)}$ も表面 構造を研究しスケッチを残している。最近では Lindeman (1969)2) および Rosenhall $(1972)^{3), 4), 5)}$ が Engs. tröm ${ }^{6)}$ の取出し標本観察法を利用し, 位相差 顕微鏡に より前庭末梢感覚器官の定量的観察を行つている. 本研 究では，銀染色法により表面構造をより明膫に観察する ことができたので, この方法により感覚上皮の全体を示 すことができた。 また膨大部稜感覚上皮の中心部と辺縁 部，球形のらおよび卵形のう斑の Striola と他の部分で の感覚細胞の特徴あるいは，分布の差異などにつき明瞭 に示すことができた。

前庭感覚上皮においては，感覚細胞に I 型と II 型があ ることはよく知られており，而型はフラスコ型であり，
П型は円柱型である．モルモットにおいては，光学顕微 鏡の焦点を感覚上 $1 / 8$ 皮の上ぐらいに合わせると，暗く小 さな環として認められるフラスコ型細胞の頸部断面と, 明るく大きな環として認められる円柱型細胞断面とを容 易に区別することができ，I 型とII型との区別はそれほ ど困難ではない9しかし本研究においては，病理解剖 で比較的早期に得られた標本においてさえ，死後変化の ために，この区別ができなかつた．しかし感覚上皮表面 の網状膜は保持されていて, 銀染色により明瞭に表面構 造を染色できたが，表面より下部の細胞体は死後変化に より膨化などの変化をきたし，正常形態を失つていたと 考えられた．実験動物でコハク酸脱水素酵素染色により 感覚細胞のみを染色し，感覚細胞数の算定を容易に行い えたが8)，ヒ卜標本では困難であつた原因は，やはりこ の死後変化によると思われた。

表 1 ヒトにおける各末梢前庭器官感覚上皮の面積および感覚細胞数

\begin{tabular}{|c|c|c|c|c|c|c|c|c|c|c|c|c|}
\hline 年令 & 性 & 側 & \multicolumn{2}{|c|}{$\begin{array}{l}\text { 前 半 規 管 } \\
\text { 数 } \\
\quad \text { 面積 } \\
\left(\mathrm{mm}^{2}\right)\end{array}$} & \multicolumn{2}{|c|}{ 外側半規管 } & \multicolumn{2}{|c|}{ 後 半 規 管 } & \multicolumn{2}{|c|}{ 球 形 の 5} & \multicolumn{2}{|c|}{ 卵 形の う } \\
\hline 42 & 男 & 右 & & & \multirow[t]{6}{*}{6902} & 0.985 & \multirow{4}{*}{6878} & \multirow{4}{*}{$\begin{array}{l}0.927 \\
0.878\end{array}$} & \multirow{3}{*}{16933} & \multirow{2}{*}{$\begin{array}{l}1.945 \\
2.479\end{array}$} & \multirow[t]{2}{*}{30624} & \multirow[t]{2}{*}{3.421} \\
\hline 45 & 男 & 左 & & 1.006 & & 1.004 & & & & & & \\
\hline 67 & 男 & 右 & \multirow{3}{*}{6820} & 0.942 & & 0.918 & & & & & 30800 & 3.613 \\
\hline 53 & 男 & 右 & & \multirow[t]{2}{*}{0.968} & & 0.928 & & & \multirow{3}{*}{14891} & \multirow{3}{*}{$\begin{array}{l}2.676 \\
1.738\end{array}$} & & 3.902 \\
\hline 48 & 女 & 左 & & & & 1.022 & \multirow[t]{2}{*}{6780} & \multirow[t]{2}{*}{0.974} & & & & 3.902 \\
\hline 15 & 男 & 右 & 7632 & 0.984 & & 0.969 & & & & & & \\
\hline \multicolumn{3}{|c|}{ （平 均） } & 7226 & 0.975 & 6902 & 0.971 & 6799 & 0.926 & 15912 & 2.209 & 30712 & 3.577 \\
\hline
\end{tabular}




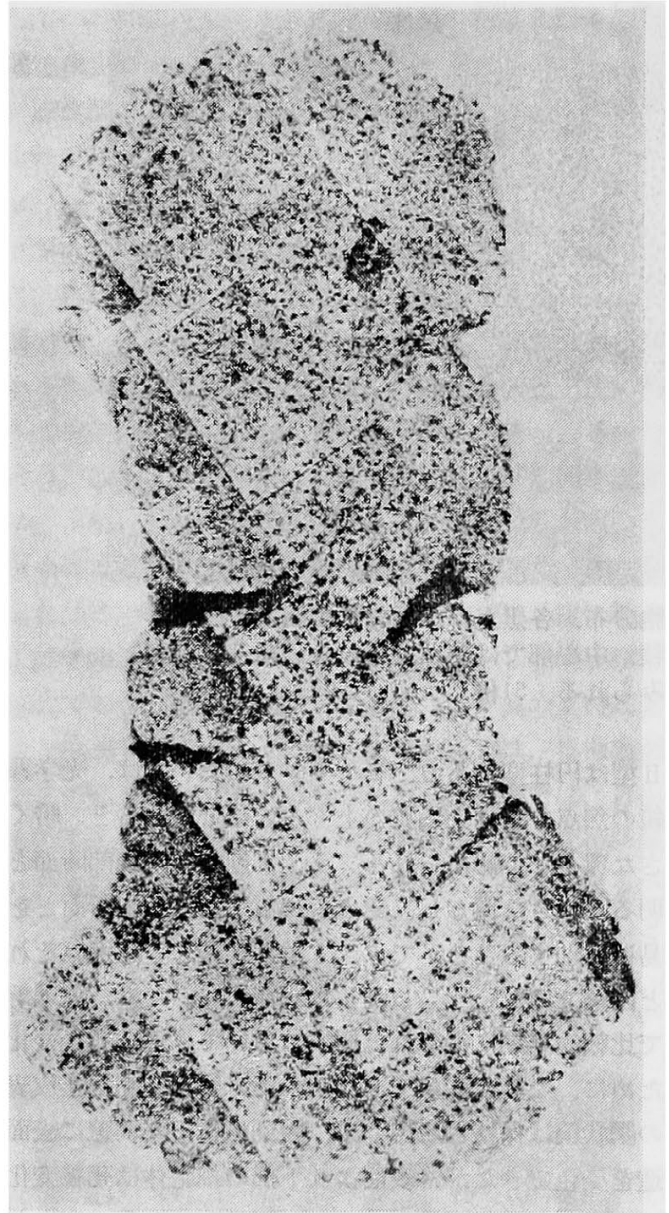

図4七下外側半規管膨大部稜感覚上皮の全体像. 48才女. 左外側半規管膨大部稜. 感覚細胞およ び支持細胞を全域にわたり明䀢に識別できる。 102倍.

本研究においては膨大部稜感覚上皮の全体表面像を， 写真を組合わせることにより示し，その感覚細胞数を表 示したが Rosenhall5) によると, 前庭感覚細胞も蝸牛の 場合上同様に，かなりの程度に老人性变性により消失す るという。したがつて表示した感覚細胞数はあくまで， その年令における感覚細胞数とみるべきであろう。確か に本研究における観察でも，膨大部稜感覚上皮の中心 部, 球形のうおよび卵形のう斑感覚上皮の Striola 部 に, 感覚細胞の脱落を示唆する所見として感覚上皮にお ける細胞配列のみだれが観察され，これは年令50才以上 の場合にかなり明瞭であつた。

\section{5 まとめ}

ヒト半規管膨大部稜感覚上皮の表面構造を，銀染色に より明膫に示すことができ，また分割撮影写真を組合わ せることにより，その全体像を示した．同時にヒト半規 管膨大部稜，球形のう斑および卵形のう斑において各感 覚細胞を同定することにより，各器官における全感覚細 胞数を直接算定して表示した。

\section{参考文献}

1) Retzius, G.: Das Gehörorgan der Wirbeltiere. Samson \& Wallin, Stockholm, 1884.

2) Lindeman, H.H.: Studies on the morphology of the sensory regions of the vestibular apparatus. Ergebn. Anat. Entw. gesch., 42;1-110, 1969.

3) Rosenhall, U.: Vestibular macular mapping in man. Ann. Otol., 81 ; 339-351, 1972.

4) Rosenhall, U.: Mapping of the cristae ampullares in man. Ann. Otol., 81; 882-889, 1972.

5) Rosenhall, $U$. \& Rubin, W.: Degenerative changes in the human vestibular sensory epithelia. Acta Otolaryng., $78 ; 67-80,1975$.

6) Engström, H., Ades, H.W. \& Anderson, A.: Structural pattern of the organ of Corti. Almqvist \& Wiksell, Stockholm, 1966.

7) Schuknecht, H.: Temporal bone removal at autopsy. Arch. Otolaryng., 87 ; 129-137, 1968.

8) Watanuki, K. \& Meyer Zum Gottesberge, A.. Morphologie der Sinnesepithelien des Vestibularorgans. Tohoku J. exp. Med., 104 ; 55-13, 1971.

9) Watanuki, K., Stupp, H.F. \& Meyer Zum Gottesberge, A.. Distribution pattern of the type I and type II sensory cells on the maculae sacculi and utriculi in the guinea pig. Pract. Otorhinolaryng., $33 ; 504-311,1971$.

10) Iwata, N.: Über das labyrinth der Fledermaus mit besonderer Berücksichtigung des statischen Apparatus. Aichi Exp. Med., 2 ; 42-171, 1924.

11) Wersäll, J.: Studies on the structure and innervation of the sensory epithelium of the cristae ampullares in the guinea pig. Acta Otolaryng., Suppl. $126 ; 1-85,1956$.

（原稿受付 昭和50.9.23日） 